\title{
INTERPRETATION OF ANOMALY PATHWAYS FOR MINERALIZATION IN PARTS OF BAMENDA MASSIF, SOUTHEASTERN NIGERIA
}

\author{
Oghonyon Rorome, Ndukauba Egesi \\ Department of Geology, University of Port Harcourt, \\ Port Harcourt, Nigeria
}

\begin{abstract}
The geophysical perception of integrating Aeromagnetic and Landsat data for interpreting anomaly pathways vis-à-vis mineralization in parts of Bamenda Massif, Southeastern Nigeria, is an elegant way of understanding the tectonic frame work through structural geologic models of the subsurface rocks in the area. The data sets were analysed and interpreted models were produced using softwares such as Oasis Montaj, ArcGIS, Envy and Erdas respectively. The aim is to delineate linear geologic structures such as faults, contacts, joints and fractures (lineament analysis) within the study area in a bid to unravelling the structural patterns (trends), and the gross subsurface geology of the area which would in no doubt help in a better understanding and characterization of mineral zones in the area. The area shows zones of sporadic and narrow shaped intrusives that are clustered from the broad-long wavelength and large "bull eye" shaped anomalies that are equispaced. Clearly, these structural features indicate different tectonic stresses resulting to large scale structural deformation. Thus, this makes them complex and some of these structures are evident in the Eastern part of the map where they trend in the NE-SW strike direction as possible zones for mineral exploration. Therefore, most of the fracture zones are believed to be located at a depth range of $<246.5 \mathrm{~m}$ to $258.2 \mathrm{~m}, 258.2 \mathrm{~m}$ to $437 \mathrm{~m}, 212.9 \mathrm{~m}$ to $>626.1 \mathrm{~m}$ and $769.2 \mathrm{~m}$ to $1039.7 \mathrm{~m}$ within the subsurface. The interconnectivity of the fracture zones makes them stand out as pathways for mineralization.
\end{abstract}

Key words - Aeromagnetics, Landsat, Bamenda Massif, Structural features, Mineralization, Magnetic Anomalies.

\section{INTRODUCTION}

Geophysics is an applied science that uses basic laws and principles of physics in solving geological problems. It is a long-established science that has contributed greatly to the understanding of geological phenomena. It concerns the determination of subsurface properties and structure of the rocks within the earth by quantitative measurement of physical fields at the surface. Several alternative forms of the geophysical methods may be used for extraction of geological properties from subsurface rocks, depending on the conditions and manner of surveying: airborne, ground, borehole, etc. Each of these alternatives has its instrumental, methodical and interpretational peculiarities (Ukaigwe, 2000).

In this case, Geophysical data are but one set of parameters that add to the description of rocks and their structural relationships. By assessing such parameters in relation to other known data both geologists and geophysicists gain fresh insights into the exploration problems to be solved. This coordinated approach may seem obvious, but in practice is rarely applied (Ukaigwe, 1997).

The study on "Interpretation of anomaly pathways for mineralization in parts of Bamenda Massif, Southeastern Nigeria can be viewed from Aeromagnetic and Landsat imageries. These imageries fall within sheets 303, 304 and 305 of the study area. Perhaps, this study is significant in geology and geophysics, as it would try to interpret structural elements for mineralization or mineral resources in the area. Thereby, considering specify areas of anomalous intrusive bodies found in these areas as well as relate these attributes to the existence of geothermal and geotectonic regime in the area. The aim is to delineate linear geologic structures such as faults, contacts, 


\section{International Journal of Engineering Applied Sciences and Technology, 2020 \\ Vol. 5, Issue 5, ISSN No. 2455-2143, Pages 283-290 \\ Published Online September 2020 in IJEAST (http://www.ijeast.com)}

joints and fractures (lineament analysis) within the study area in a bid to unravelling the structural patterns (trends), and the gross subsurface geology of the area which would in no doubt help in a better understanding and characterization of mineral zones in the area.

However, several scholars have worked recently on the interpretation of subsurface anomalies and structural features that serve as pathways for mineralization and other related geologic attributes in the Southeastern region of Nigeria. Such work includes those of (Ugwu \& Nwosu, 2009; Selemo \& Akaolisa, 2010; Chikwendu \& Diugo, 2011; Oden, et al., 2012; Amah, et al., 2012; Alain, et al., 2012; Adetona \& Abu, 2013; George, et al., 2013; David \& Marius, 2013; Obi, et al., 2013; Goodhope \& Luke, 2013; Onuba, et al., 2013; Opara, et al., 2014; Ezema, et al., 2014). Their works are related to the resolution of magnetic lineaments, analyse its relationship to the tectonic fabric and to estimate the depth of perturbing bodies.

\section{GENERAL GEOLOGY OF THE REGION}

The study area is part of the Bamenda highlands of Cameroon into Southeastern Nigeria and it lies within latitudes $06^{\circ} 0^{\prime} 00^{\prime \prime} \mathrm{N}$ to $07^{\circ} 0^{\prime} 00^{\prime \prime} \mathrm{N}$ and longitudes $08^{0} 00^{\prime} 00^{\prime \prime} \mathrm{E}$ to $09^{0} 30^{\prime} 00^{\prime \prime} \mathrm{E}$ with the famous Obudu Plateau in the North-eastern part located North of Ikom in Cross River State. It is believed that the study area, Bamenda Massif belong to the Precambrian Basement Complex of Nigeria in age (Ekwueme, et al., 1995).

The oldest rock in the Southeastern area is the banded gneisses and the youngest is dolerite which is part of the igneous intrusives in the area. These rock units are overlain by Cretaceous- Tertiary sediments of the Calabar Flank (Ekwueme, 2003). Perhaps, most of the mappable rock units in the area are of metamorphic origin, although, intruded by igneous rocks such as pegmatite, granodiorite, diorite, dolerite, etc., (Rahaman, et al., 1981).

The rocks are bounded to the West by Cretaceous and younger sediments of Benue Trough, to the East of the prominent Cameroon Volcanic Line, and to the North of the Ogoja Province and the famous Obudu Plateau as shown in Fig. 1. The study area is located within latitudes $06^{\circ} 0^{\prime} 00^{\prime \prime} \mathrm{N}$ to $07^{\circ} 0^{\prime} 00^{\prime \prime} \mathrm{N}$ and longitudes $08^{0} 0^{\prime} 00^{\prime \prime} \mathrm{E}$ to $09^{0} 30^{\prime} 00^{\prime \prime} \mathrm{E}$ as shown in Fig.

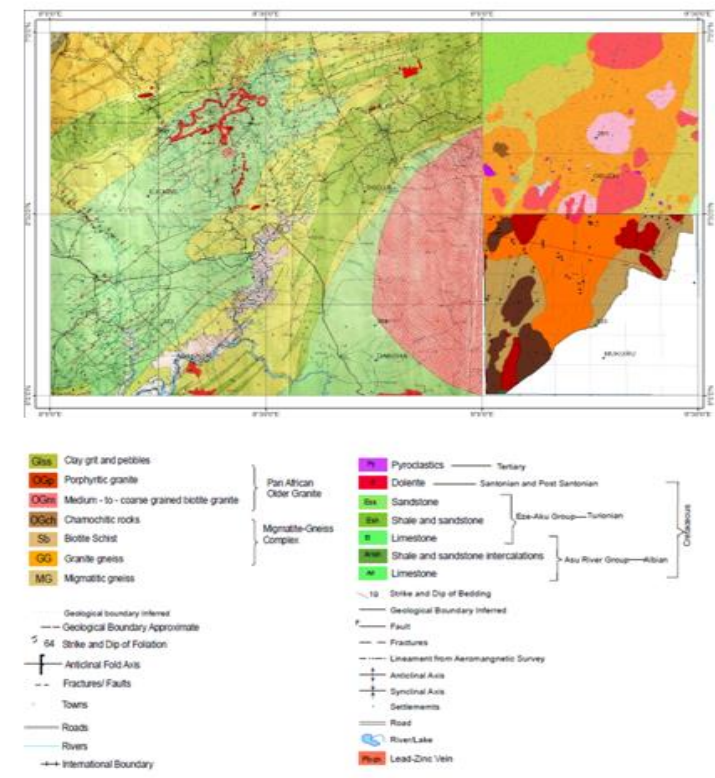

Fig. 1. Geologic map of the study area (Nigerian Geological Survey Agency, 2006).

\section{MATERIALS AND METHODS}

\section{A. Data Sets and Source}

The data sets used in this research work include Aeromagnetic, Landsat data (sheets: 303, 304 and 305) and Geologic map (scale of 1: 100,000) of the study area which were obtained from the Nigerian Geological Survey Agency (NGSA), Abuja Federal Capital Territory, Nigeria.

\section{B. Aeromagnetic Data Analysis}

The concept of Aeromagnetic data processing involves accurate enhancement of the shortwavelength and linear features. In that regard, the Aeromagnetic data was first re-gridded with a grid-cell spacing of $252 \mathrm{~m}$ and was subjected to regional/residual separation to isolate shortwavelength signals which are more suitable for highresolution mapping of shallow magnetic boundaries from long-broad wavelength signals. The regional/residual separation was made by upward continuation of the total magnetic intensity aeromagnetic grid. In this way, the upward continuation transformation attenuates the highfrequency signal components and therefore, tends to emphasize deep, regional-scale magnetic anomalies. Subtraction of the low-frequency upward-continued data from the original grid produces a residual map that is enhanced in the short-wavelength signal. The 


\section{International Journal of Engineering Applied Sciences and Technology, 2020 Vol. 5, Issue 5, ISSN No. 2455-2143, Pages 283-290 \\ Published Online September 2020 in IJEAST (http://www.ijeast.com)}

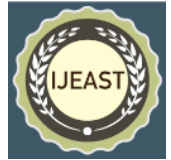

enhancement of magnetic anomalies that are associated with faults and other structural discontinuities were achieved by the application of Vertical Derivative to the residual map in Fig. 5. The reprocessed Aeromagnetic data set is significantly enhanced in high frequencies and is much better suited to detailed regional shallow mapping and analysis of basement magnetic boundaries.

\section{Landsat Data Analysis}

Satellite imagery provides digital image of the earth at specific wavelength within the electromagnetic spectrum. Various features on the earth either natural or man-made give distinguishable signature of the electromagnetic radiation. This signature helps categorize the data into different features for various geographic applications such as land cover, vegetation types, terrain conditions, builtup areas etc. It appears to be a solution to providing data owing to its synoptic capability, spectral, spatial and temporal resolution. In addition to that, the technique acquires spatially continuous data unlike field sensors (airborne and space borne) applied in hydrological studies.

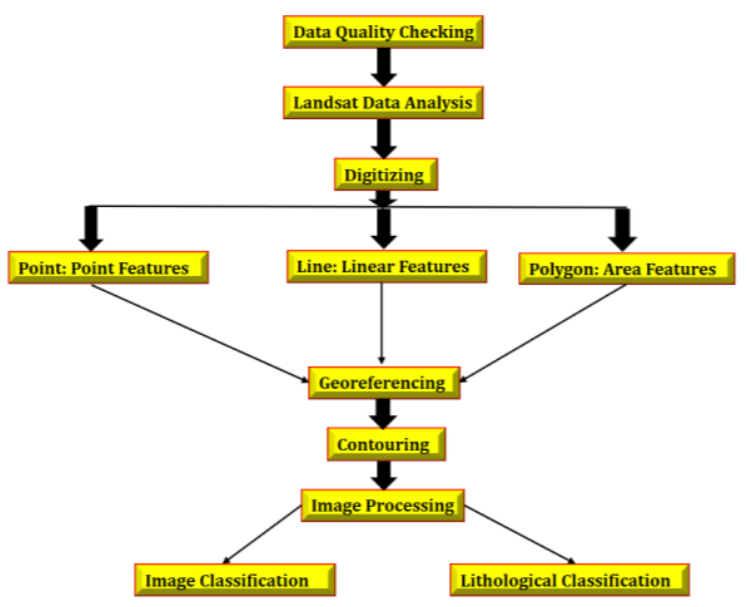

Fig. 2. A technical work flow of the Landsat data analysis.

\section{RESULTS AND DISCUSSION}

\section{A. Results of Aeromagnetic Data}

Indeed, geophysical data are embodiment of subsurface changes in relation to the various geological processes such as deformation, displacement, tensional and compressional stresses that can result to structural features emanating from subsurface to near surface Earth. However, these sorts of geophysical data can be acquired by land or airborne surveys. Consequently, the data are processed and interpreted to understand the structural elements at the subsurface rocks from which possible mineralizations can be explored and exploited in Fig. 3, 4 and 5.

Basically, the regional anomaly is caused by deep seated effects like volcanism, tectonism and intrusion at depth in Fig. 4, 6 and 7. However, this can be interpreted during processing of the Aeromagnetic data which is done using sophisticated softwares (such as Oasis Montaj) to remove the regional effect to obtain the residual anomaly in Fig. 4 and 5.

The vertical derivative map and other improved resolution maps that are associated with it, demonstrate a vivid picture of the subsurface pervasive structures. However, these structures can be seen in the Northern part of the map that shows a major fault line which runs down to the Southern part and another in the South-western part of the map. The configuration of positive anomalies in the Northern and Southern parts of the area may be attributed to deep-seated basement structures and this in effect, suggests that the total magnetic intensity of the anomalies is strongly influenced by the regional tectonics existing at the subsurface basement rocks in Fig. 5, 6 and 7. However, the Aeromagnetic maps which illustrate the presence of fracture zones in different parts of the area, show that these zones are prominently oriented in the NE-SW and NW-SE directions in Fig. 5.

This separates zones of sporadic and narrow shaped dike intrusions that are clustered together from the broad-long wavelength and large "bull eye" shaped dike intrusions that are equispaced. Clearly, these structural features are associated to long and short wavelength anomalies, indicating that they are connected to different tectonic stresses resulting to large scale structural deformation. Thus, this makes them complex and some of these structures are evident in the Eastern part of the map where they trend in the NE-SW strike direction as possible zones for mineral exploration in Fig. 5.

Therefore, most of the fracture zones are believed to be located at a depth range of $<246.5 \mathrm{~m}$ to $258.2 \mathrm{~m}$, $258.2 \mathrm{~m}$ to $437 \mathrm{~m}, 212.9 \mathrm{~m}$ to $>626.1 \mathrm{~m}$ and $769.2 \mathrm{~m}$ to $1039.7 \mathrm{~m}$ within the subsurface in Fig. 8. The interconnectivity of the fracture zones makes them stand out as pathways for mineralization.

In addition, the Aeromagnetic map in Fig. 3 was further interpreted quantitatively for computing and 


\section{International Journal of Engineering Applied Sciences and Technology, 2020 Vol. 5, Issue 5, ISSN No. 2455-2143, Pages 283-290 \\ Published Online September 2020 in IJEAST (http://www.ijeast.com)}

magnetic parameters that would aid the understanding of subsurface activities that gave rise to the changes in magnetic anomalies, the possible source of the anomalous zones, the geometry of the anomalies, depth to basement surface, width of the causative body, amplitude and wavelength of the anomaly structures in Table- $\mathbf{1}$.

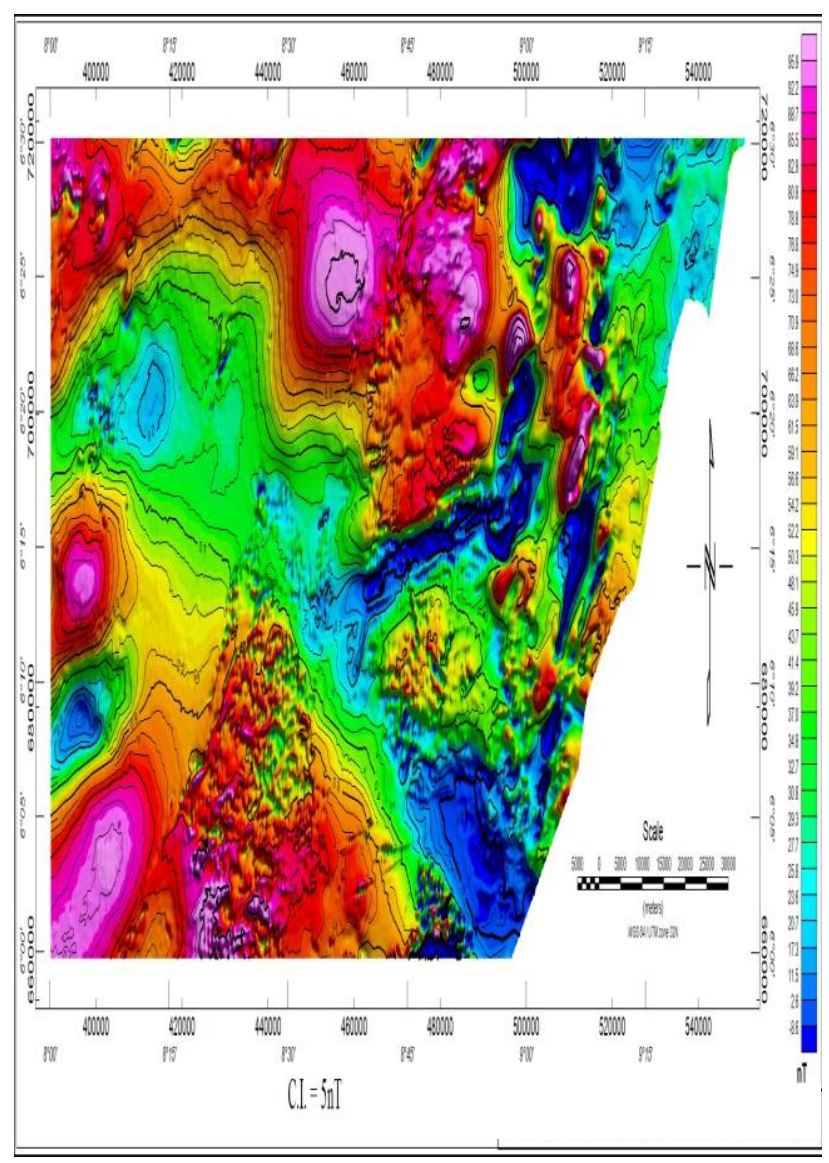

Fig. 3. Total magnetic intensity contour map of Bamenda Massif.

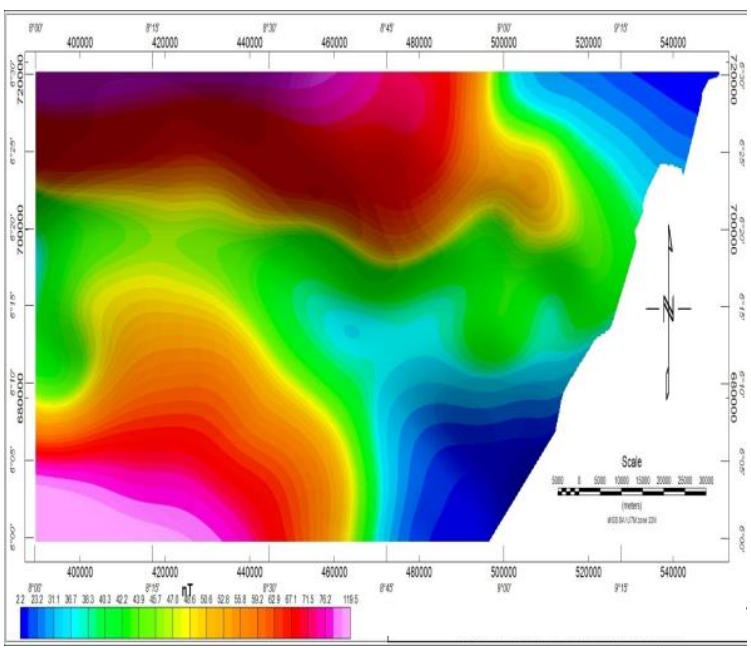

Fig. 4. Regional map of Bamenda Massif

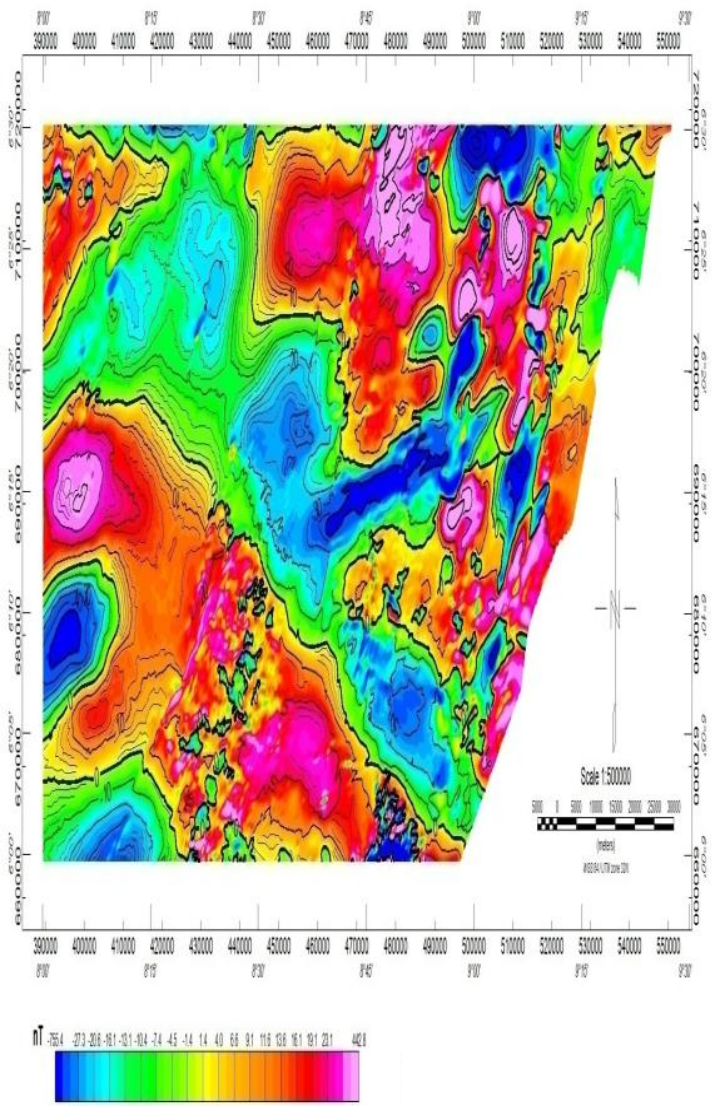

Fig. 5. Residual map of Bamenda Massif. 


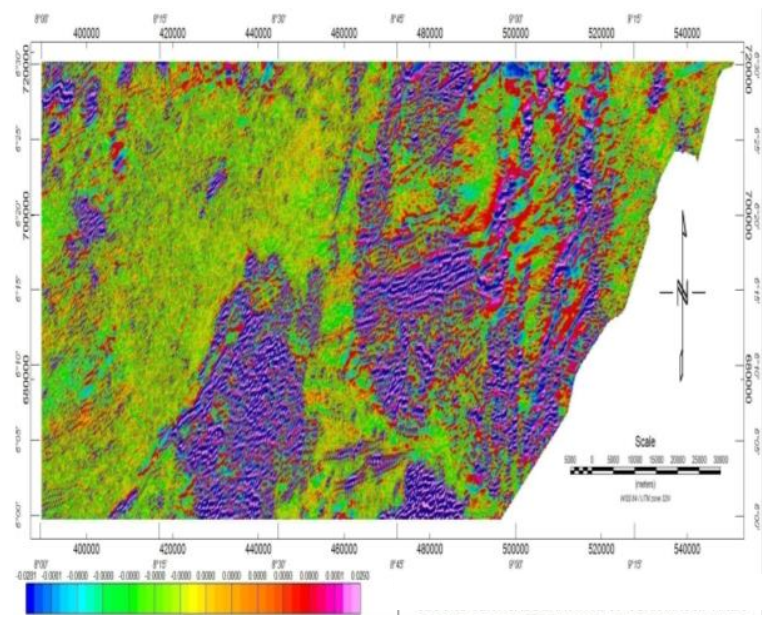

Fig. 6. Vertical Derivative Map of Bamenda Massif.

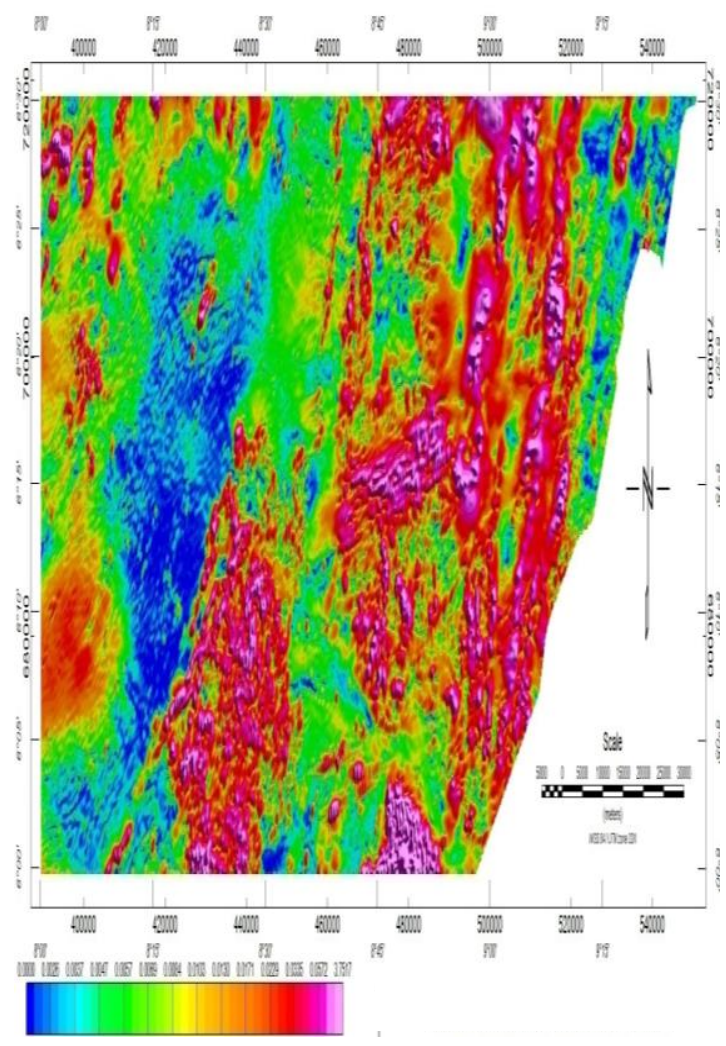

Fig. 7. Analytical Signal Map of Bamenda Massif.

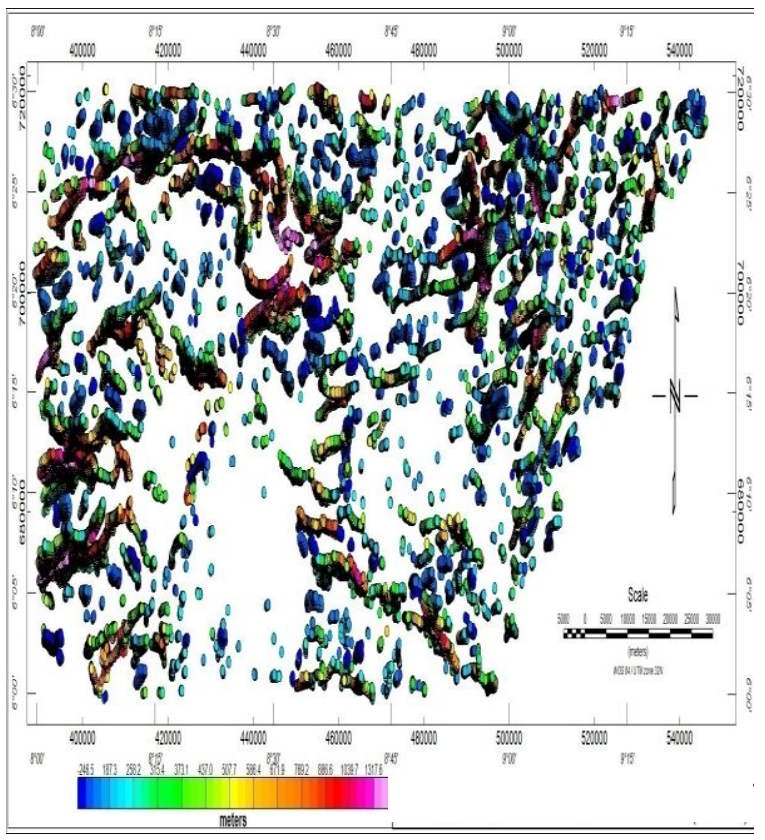

Figure 8. Euler Deconvolution Map and depth estimate to basement undulating surface (Note: The following coloured spots have depth estimates of: blue $=<246.5-258.2 \mathrm{~m}$; yellow $=437.0-769.2 \mathrm{~m} ;=$ $1039.7->1317.6 \mathrm{~m} ;$ green $=258.2-437.0 \mathrm{~m} ;$ red $=$ $769.2-1039.7 \mathrm{~m}$ and black $=<0)$.

\section{B. Results of Landsat Data}

The regional geologic structures in parts of Southeastern Nigeria have a complex geology, however, the use of integrated approach of Aeromagnetic and Landsat data can vividly delineate the subsurface structural attributes for possible mineralization of magnetic minerals in veins and fissures.

The models in Fig. 9 and 10 confirm the morphological difference and the tectonical subdivision into tentative sequence of events corresponding to the central part of the Landsat data and to identify the tectonic boundaries separating them at depth.

Apparently, the Landsat data shows a clear view of the shear zone in Fig. 11). Typically, this zone illustrates subsurface structural deformation activities that is related to the rifting of the Southern Nigeria margin system. However, a reconstruction of the structural events on the Landsat map that is on top of the 3D model in Fig. 11 shows that a large scale structural deformation could be responsible for the rifting and then, drifting of the two adjacent blocks in the form of 


\section{International Journal of Engineering Applied Sciences and Technology, 2020 \\ Vol. 5, Issue 5, ISSN No. 2455-2143, Pages 283-290 \\ Published Online September 2020 in IJEAST (http://www.ijeast.com)}

a shearing motion which resulted to faulting and uplift of the adjacent blocks in Fig. 10 and 11.

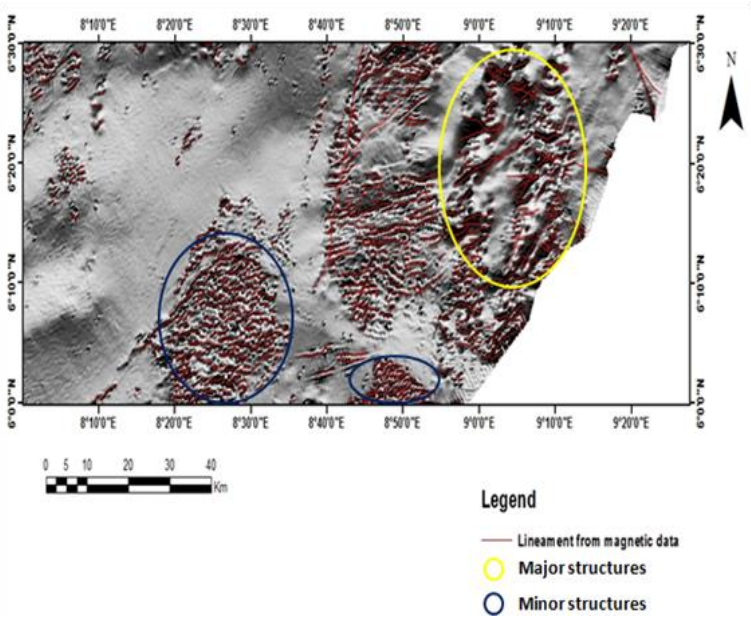

Fig. 9. Lineament map from Landsat data showing areas of major and minor structures within the study area.

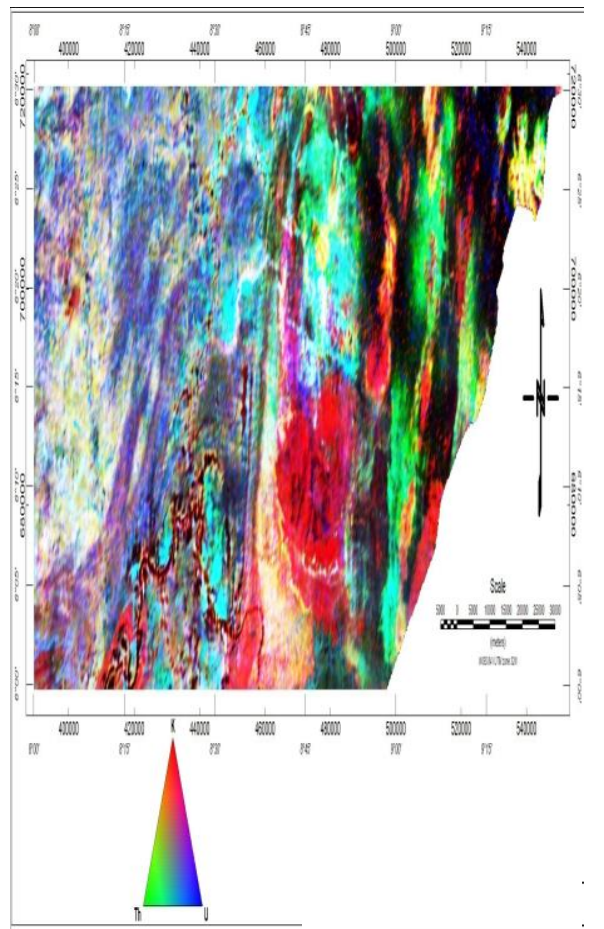

Fig. 10: Ternary image map defining regions of magnetic anomalies with the help of response from radioactive elements beneath the earth.

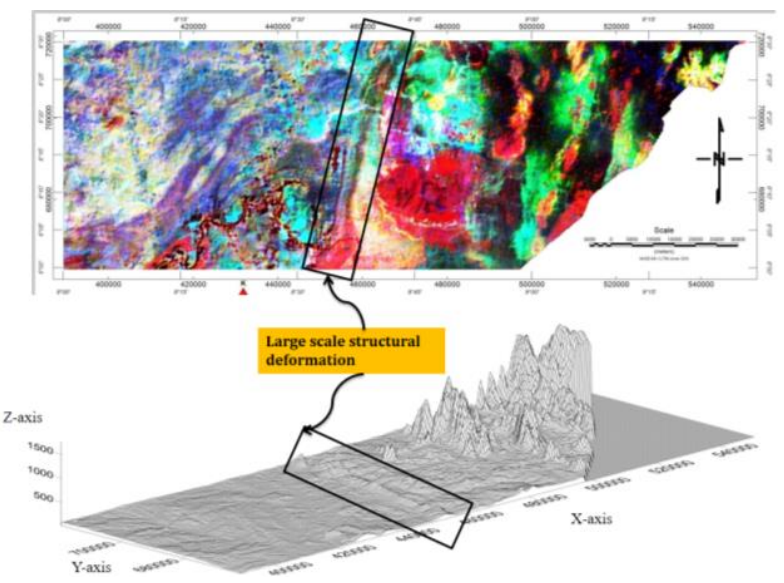

Fig. 11. Large scale structural deformation on both Landsat imagery (at the top) and 3-D structural model (at the bottom).

Table-1 Quantitative parameters computed from Aeromagnetic map.

\begin{tabular}{|c|c|c|c|c|c|c|c|c|c|c|}
\hline \multirow[t]{2}{*}{$S / \mathrm{N}$} & \multirow{2}{*}{\begin{tabular}{|l} 
PROFILE \\
ID
\end{tabular}} & \multicolumn{3}{|c|}{ Depth, Z (m) } & \multirow{2}{*}{$\begin{array}{l}\Delta \mathrm{T} \\
(\mathrm{nT})\end{array}$} & \multirow{2}{*}{\begin{tabular}{|c|} 
Dip \\
(degree)
\end{tabular}} & \multirow{2}{*}{$\begin{array}{c}\mathrm{K} \\
\text { (c.g.s.) }\end{array}$} & \multirow{2}{*}{$\begin{array}{l}W \\
(\mathrm{~m})\end{array}$} & \multirow{2}{*}{$\begin{array}{c}\% \\
\text { Magnetite }\end{array}$} & \multirow{2}{*}{$\begin{array}{l}\text { Possible } \\
\text { rock type }\end{array}$} \\
\hline & & H.S.D & $s$ & $P$ & & & & & & \\
\hline 1 & $\mathrm{AA}_{1}$ & \begin{tabular}{|l|l|}
1123.2 & \\
\end{tabular} & 537.6 & 979.2 & \begin{tabular}{|l|}
98.5 \\
\end{tabular} & 10 & 0.0045 & \begin{tabular}{|l|}
326.4 \\
\end{tabular} & 1.4 & \begin{tabular}{|l|} 
Dolerite \\
\end{tabular} \\
\hline 2 & $\mathrm{AB}_{1}$ & 936 & \begin{tabular}{|l|l|}
892.8 \\
\end{tabular} & \begin{tabular}{|l|l|}
964.8 \\
\end{tabular} & 89 & 39 & 0.00403 & 312 & 1.2 & $\begin{array}{l}\text { Granite } \\
\text { gneiss }\end{array}$ \\
\hline 3 & $\mathrm{AC}_{1}$ & \begin{tabular}{|l|l|}
270.4 &
\end{tabular} & \begin{tabular}{|l|l|}
268.8 & \\
\end{tabular} & 374.4 & 78.5 & 46 & 0.00356 & 90 & 1.1 & $\begin{array}{l}\text { Porphyritic } \\
\text { Granite }\end{array}$ \\
\hline 4 & $\mathrm{AD}_{1}$ & 206.7 & \begin{tabular}{|l|l|}
173.4 \\
\end{tabular} & 945.9 & \begin{tabular}{|l|l|}
70.8 \\
\end{tabular} & 15 & 0.0032 & \begin{tabular}{|l|l|}
68.7 & \\
\end{tabular} & \begin{tabular}{|l|l|}
0.98 & \\
\end{tabular} & Diorite \\
\hline 5 & $\mathrm{AE}_{1}$ & \begin{tabular}{|l|}
276.9 \\
\end{tabular} & \begin{tabular}{|l|}
108.6 \\
\end{tabular} & 261.9 & 79 & 28 & 0.0036 & \begin{tabular}{|l|}
87.3 \\
\end{tabular} & \begin{tabular}{|l|}
1.10 \\
\end{tabular} & $\begin{array}{l}\text { Porphyritic } \\
\text { Granite }\end{array}$ \\
\hline 6 & $\mathrm{AF}_{1}$ & 912.6 & \begin{tabular}{|l|l|}
198.6 \\
\end{tabular} & \begin{tabular}{|l|l|}
897.3 \\
\end{tabular} & 75 & 31 & 0.0034 & \begin{tabular}{|l|l|}
299.1 \\
\end{tabular} & 1.05 & \\
\hline 7 & $\mathrm{AG}_{1}$ & 219.7 & \begin{tabular}{|l|l|}
246.6 \\
\end{tabular} & 368.1 & 66.2 & 52 & \begin{tabular}{|l|}
0.0029 \\
\end{tabular} & \begin{tabular}{|l|l|}
82.2 & \\
\end{tabular} & \begin{tabular}{|l|l|}
0.92 \\
\end{tabular} & \begin{tabular}{|l|} 
Diorite \\
\end{tabular} \\
\hline 8 & $\mathrm{AH}_{1}$ & 162.5 & \begin{tabular}{|l|l|}
197.4 \\
\end{tabular} & 395.1 & 71.2 & 42 & 0.0032 & \begin{tabular}{|l|l|}
65.8 & \\
\end{tabular} & \begin{tabular}{|l|l|}
0.98 & \\
\end{tabular} & \\
\hline 9 & $\mathrm{AI}_{1}$ & \begin{tabular}{|l|}
408.2 \\
\end{tabular} & 228 & 252 & 69.5 & 49 & 0.0031 & 84 & 0.95 & \\
\hline 10 & $A I_{1}$ & \begin{tabular}{|l|l|}
878.8 & \\
\end{tabular} & \begin{tabular}{|l|l|}
370.8 \\
\end{tabular} & 835.2 & 91.3 & 13 & 0.0041 & \begin{tabular}{|l|l|}
278.4 & \\
\end{tabular} & \begin{tabular}{|l|}
1.26 \\
\end{tabular} & \begin{tabular}{|l} 
Granite \\
gneiss
\end{tabular} \\
\hline & RAGE & 539.5 & 322.26 & 627.39 & \begin{tabular}{|l|l|}
142.98 \\
\end{tabular} & 32.5 & 0.0035 & 169.39 & \begin{tabular}{|l|l|}
1.094 \\
\end{tabular} & \\
\hline
\end{tabular}




\section{International Journal of Engineering Applied Sciences and Technology, 2020 Vol. 5, Issue 5, ISSN No. 2455-2143, Pages 283-290 \\ Published Online September 2020 in IJEAST (http://www.ijeast.com)}

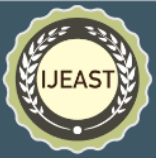

\section{DISCUSION}

The study area is the Bamenda Massif shown on Aeromagnetic and Landsat maps. This area occupies part of the South-eastern region of Nigeria and extends up to the Cameroon volcanic ridge. The data sets were analysed and interpreted models of Aeromagnetic and Landsat were produced using geophysical softwares such as Oasis Montaj, ArcGIS, Envy and Erdas respectively.

However, this study demonstrates the use of Landsat imagery, digitized Aeromagnetic and geological maps in Fig. 1, 3 and 9 for mapping and analysing lineaments in the Basement Complex region of South-eastern Nigeria. The extracted lineaments were geophysically analyzed (region-residual separation) to determine their trends and anomalous intensities to generate lineament maps for subsurface evaluation in Fig. 3, 4, 5, 6, 7,8 and 9.

Indeed, the fracture analyses of the lineament characteristics indicate that the area has numerous long and short fractures whose structural trends are striking mainly in the NE-SW and NW-SE directions in Fig. 5, 6 and 7 and in a similar pattern to the initial rifting of the Southern Nigerian margin system. However, the cross-cutting lineaments are relatively high in areas around the North-eastern, Southern and South-western parts of the study area, and relatively low in the other areas in Fig. 6 and 7.

It is worth noting, that as depth increases, signal amplitude in the different parts of the study area contained in the data, decreases or decays in Fig. 3, 5 and 8 . Therefore, the deeper the anomaly, the lower the anomaly amplitude which has longer (broad) wavelength and poor resolution. While the shallower the anomaly (i.e., those at shallow depth), the higher the anomaly amplitude which produces shorter wavelength and better resolution quality. However, anomalies located at greater depth but are seen to portray lower anomaly amplitude would be processed for improving the resolution quality for a reasonable geological and geophysical interpretation in Fig. 5.

Thus, the magnetic parameters computed is interpreted both qualitatively and quantitatively in order to establish a regional tectonic framework by creating a model that would in turn used to make meaningful geologic interpretation about the thickness of the sedimentary cover, a structural modeling, source producing the anomaly, susceptibility of the anomaly, depth to basement and anomalous zones that are associated with mineralization in the area and relate these anomalies to the known geology of the study area in Tables-1.

\section{CONCLUSION}

The geophysical perception of integrating Aeromagnetic and Landsat data for interpreting anomaly pathways vis-à-vis mineralization in parts of Bamenda Massif, Southeastern Nigeria, is an elegant way of understanding the tectonic frame work through structural geologic models of the subsurface rocks in the area.

However, analysis of the Aeromagnetic data reviewed certain geophysical parameters about the subsurface anomalies formed within the basement and overlying sedimentary rocks. Thus, these parameters which describe the properties of these anomalies within the rocks show an average depth to basement surface of 539.5m; Anomaly amplitude of $142.98 \mathrm{nT}$; Dip of $32.5^{0}$; Magnetic susceptibility of $3.5 \times 10^{-3}$ c.g.s unit; Width of $169.39 \mathrm{~m}$; Percentage magnetite of 1.094 and the possible rock types observed are Dolomite, Granite-gneiss, Porphyritic-granite and Diorite respectively.

Furthermore, analysis of the Landsat data displays some peculiarities in defining the structural trends/pathways for mineralization. In this way, the structures formed within the zones may have been triggered by tectonic stresses within the rocks. And these stress components result in the formation of structural lineaments in the Northeastern, Southern and Southwestern parts of the area.

The sequence of events from the different models reviewed rifting and drifting processes within the rocks, giving rise to large scale structural deformation of these rocks. The deformational process created openings within the rocks in the form of cracks, fissures, veins, crevasses, etc., that could serve as accommodation space for mineralization during magmatic differentiation at depth.

\section{ACKNOLEDGEMENT}

This paper is part of $\mathrm{Ph} . \mathrm{D}$ Thesis that was elaborate at the University of Port Harcourt.

\section{REFERENCES}

[1]. Ukaigwe N. F. (2000). A First Course in Seismic Exploration on, (pp. 417).

[2]. Ukaigwe N. F. (1997). Digital Geophysical Data Processing (Theory and Applications) on, (pp. 247302). 


\section{International Journal of Engineering Applied Sciences and Technology, 2020 Vol. 5, Issue 5, ISSN No. 2455-2143, Pages 283-290 \\ Published Online September 2020 in IJEAST (http://www.ijeast.com)}

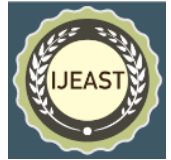

[3]. Ugwu, S. A. and Nwosu, J. I. (2009). Detection of fractures for groundwater development in Oha Ukwu using Electromagnetic profiling. Department of Geology, University of Port Harcourt, Rivers State, Nigeria, (pp. 59-63).

[4]. Selemo, A. O. I. and Akaolisa, C. Z. (2010). Tectonic features interpreted from aeromagnetic maps of Okigwe - Oguta axis, South of Benue Trough, Nigeria. Department of Geosciences, Federal University of Technology, Owerri, Nigeria, (pp. 24502457).

[5]. Chikwendu, N. O. and Diugo, O. I. (2011). Structural analysis of the aeromagnetic data of part of the Imo River Basin, Southeastern Nigeria. Department of Geosciences Federal University of Technology, Owerri, Nigeria on, (pp. 48-59).

[6]. Oden, M. I., Okpamu, T. A. and Amah, E. A. (2012). Comparative Analysis of Fracture Lineaments in Oban and Obudu Areas, SE Nigeria. Department of Geology, University of Calabar, Calabar, Nigeria, (pp. 36-47, 2012).

[7]. Amah, E. A., Esu, E. O., Oden, M. I. and Anam, G. (2012). Evaluation of Old Netim Basement Rocks (South-Eastern Nigeria) for Construction Aggregates. Department of Geology, University of Calabar, Nigeria, (pp. 90-98).

[8]. Alain, N. S. F., Theophile, N. M., Eliezer, M. D. and James, D. F. (2012). Delineation of tectonic lineaments using aeromagnetic data for the south-east Cameroon area on, (pp. 175-192, 2012).

[9]. Adetona, A. A. and Abu, M. (2013). Investigating the Structures within the Lower Benue and Upper Anambra Basins, Nigeria, Using First Vertical Derivative, Analytical Signal and Centre for Exploration Targeting Plug-In. Department of Physics on, (pp. 104-112).

[10]. George, A. M., Abong, A. A. and Obi, D. A. (2013). Fracture zone detection using very low frequency (VLF) electromagnetic method in parts of Oban Massif, Southeastern Nigeria. Department of Physics, University of Calabar, Calabar, Nigeria, (pp. 104-121).

[11]. David, I. I. and Marius, N. U. (2013). Interpretation of Aeromagnetic Anomalies Over Some Parts of Lower Benue Trough Using Spectral Analysis Technique on, (pp. 153-165, 2013).
[12]. Obi, D. A., Ilozobhe, A. J. and Lebo, S. E. (2013). Aeromagnetic Study of Oil Seepage along the Basement Flank of Part of the Lower Benue Trough, South eastern Nigeria on, (pp. 22-29).

[13]. Goodhope, A. and Luke, M. (2013). Structural Interpretation of Abakiliki - Ugep, using Airborne Magnetic and Landsat Thematic Mapper (TM) Data. Department of Geology University of Nigeria, Nsukka, Enugu State Nigeria on, (pp. 137-148).

[14]. Onuba, L. N., Onwuemesi, A. G., Egboka1, B. C., Anudu, G. K. and Omali, A. (2013). A Review of Hydrocarbon Prospects in the Lower Benue Trough, Nigeria: Another Insight from Potential Field Study. Adapted from extended abstract prepared in conjunction with oral presentation at American Association of Petroleum Geologist (AAPG) Annual Convention and Exhibition, Pittsburgh, Pennsylvania on, (pp. 30-50).

[15]. Opara, A. I., Onyewuchi, R. A., Selemo, A. O. I., Oyenkuru S. O. and Obechu, B. O. (2014). Structural and tectonic features of Ugep and Environs, Calabar Flank, Southeastern Nigeria on, (pp. 33-54).

[16]. Ezema P. O., Eze I. D. Ugwu, G. Z. and Abdullahi U. A. (2014). Hydrocarbon and Mineral Exploration in Abakaliki, South Eastern Nigeria. Department of Physics and Astronomy, University of Nigerian, Nsukka, (pp. 24-30).

[17]. Ekwueme, B. N., Eyo, E. N. and Sunday, W. P. (1995). Geological Excursion Guide to Oban Massif, Calabar Flank and Mamfe Embayment, Southeastern Nigeria. The 31st Annual Conference of the Nigeria Mining and Geosciences Society, Calabar, Nigeria on, (pp. 1-36).

[18]. Ekwueme, B. N. (2003). The Precambrian Geology and Evolution of South eastern Nigerian Basement Complex on, (pp. 135- 140).

[19]. Rahaman, A. M. S., Ukpong, E. E., and Azmatullah, M. (1981). Geology of parts of the Oban Massif South-eastern Nigeria on, (pp. 60-65).

[20]. Nigerian Geological Survey Agency (2006). Geological and Mineral Resources Map of Nigeria. Ministry of Mines and Steel Development Abuja, Nigeria on, (pp. 21-56). 